\title{
The Spatial Dimensions of Early Mesopotamian Urbanism: The Tell Brak Suburban Survey, 2003-2006
}

\section{Citation}

Ur, Jason, Philip Karsgaard, and Joan Oates. 2011. The Spatial Dimensions of Early Mesopotamian Urbanism: The Tell Brak Suburban Survey, 2003-2006. Iraq 73: 1-19.

\section{Published Version}

http://www.britac.ac.uk/INSTITUTES/IRAQ/journal.htm

\section{Permanent link}

http://nrs.harvard.edu/urn-3:HUL.InstRepos:5366597

\section{Terms of Use}

This article was downloaded from Harvard University's DASH repository, and is made available under the terms and conditions applicable to Other Posted Material, as set forth at http:// nrs.harvard.edu/urn-3:HUL.InstRepos:dash.current.terms-of-use\#LAA

\section{Share Your Story}

The Harvard community has made this article openly available. Please share how this access benefits you. Submit a story.

Accessibility 


\section{VOLUME LXXIII・2011}

\section{GONTENTS}

Editorial

iii

Obituaries: Dr Donny George Youkhanna, Mrs Rachel Maxwell-Hyslop

Jason Ur, Philip Karsgandd and Joan OAtes: The spatial dimensions of early Mesopotamian urbanism: The Tell Brak suburban survey, 2003-2006

Garlo Golantoni and Jason Ur: The architecture and pottery of a late third-millennium residential quarter at Tell Hamoukar, north-eastern Syria

David Kertai: Kalhu's palaces of war and peace: Palace architecture at Nimrud in the ninth century BC

Joshua Jeffers: Fifth-campaign reliefs in Sennacherib's "Palace Without Rival" at Nineveh

M. P. Stregk and N. Wasserman: Dialogues and riddles: Three Old Babylonian wisdom texts

Grégory Ghambon and Eleanor Robson: Untouchable or unrepeatable? The upper end of the Old Babylonian metrological systems for capacity and area

Nicholas Postgate: Making tablets or taking tablets? tuppa/u sabātu in Assyria

URI GABbAY: A fragment of a Sumerian lament: BM 65463, Tablet XI of the balaĝ úru àm-ma-ir-ra-bi

Jan Keetman: Eine als Ziqqurrat gedeutete Skizze einer Treppenanlage

Hugh Kennedy: Feeding the five hundred thousand: Cities and agriculture in early Islamic Mesopotamia

Stephanie Rost and Abdulamir Hamdani, with illustrations by Steven George: Traditional dam construction in modern Iraq: A possible analogy for ancient Mesopotamian irrigation practices

Abstracts in Arabic

PUBLISHED BY THE

BRITISH INSTITUTE FOR THE STUDY OF IRAQ

(GERTRUDE BELL MEMORIAL)

10 Carlton House Terrace, London SW1Y 5AH

www.bisi.ac.uk

ISSN 0021-0889 


\title{
THE SPATIAL DIMENSIONS OF EARLY MESOPOTAMIAN URBANISM: THE TELL BRAK SUBURBAN SURVEY, 2003-2006
}

\author{
By JASON UR, PHILIP KARSGAARD and JOAN OATES
}

The 2003-2006 Suburban Survey at Tell Brak investigated the spatial dimensions of the city's urban origins and evolution via intensive systematic surface survey. This report places this research in the broader context of research on Near Eastern urban origins and development, describes the survey and remote sensing methods and summarises the results, which challenge several long-held models for the timing and geographical origins of urbanism in the Near East. Urbanism at Brak coalesced over the course of several centuries in the late fifth and early fourth millennia $\mathrm{BC}$, when it evolved from a series of spatially discrete settlement zones into a 130-hectare city, without the benefit of irrigated agriculture. Other urban phases occurred in the late third millennium ( 70 hectare) and in the Late Bronze Age (45 hectare), all with different urban morphologies. Brak's final settlement occurred in the Abbasid period, when a 14-hectare town grew around the Castellum. In addition to the timing, growth and variability of urban form at the site, the Suburban Survey also documented well preserved off-site ancient landscapes of tracks, field systems and irrigation canals.

The city has long been a primary locus of research in Mesopotamian archaeology, not only because of its centrality within Mesopotamian society but also because of its early and pristine appearance as compared to other regions. Over a century of scholarship, a narrative has emerged on the form and development of the city. This consensus states that the Mesopotamian city was a dense and nucleated settlement, with narrow streets dividing otherwise continuous blocks of domestic architecture and the structures housing large institutions. Cities originated as villages, often clustered around a central temple, which expanded outward but maintained a constant density. The earliest cities were in southern Mesopotamia and formed in the late fourth millennium BC. Several expanded in the early third millennium and were joined by others in a constellation of city-states. Urbanism eventually appeared in areas peripheral to southern Mesopotamia, and could be explained by the diffusion of the concept either in the course of the Uruk expansion of the fourth millennium or during the time of the Early Dynastic city-states.

This extremely durable narrative is now challenged by excavation and systematic survey in one of the so-called "peripheral" regions, northern Mesopotamia. Through this research, Tell Brak, in the Upper Khabur basin of north-eastern Syria, can now be recognized as an indigenous city at least a half millennium before the Uruk expansion. Furthermore, its initial structure and subsequent development appear at odds with the conventional southern Mesopotamian model. Near Eastern urbanism had, at a minimum, a multi-centric origin. In this preliminary report we present the empirical data for the appearance of urban form at Brak via the Tell Brak Suburban Survey, which complements data from the Tell Brak Sustaining Area Survey. Furthermore, we demonstrate how that form fluctuated over five millennia and consider the ramifications of its changing nature for existing models of the Mesopotamian city. ${ }^{1}$

\section{Past and present research at the Tell Brak settlement complex}

Brak's place in ongoing debates about the origins and development of Mesopotamian urbanism has always been firmly anchored in an extensive excavation dataset that describes monumental

\footnotetext{
${ }^{1} \mathrm{We}$ are indebted to many people and institutions for enabling and encouraging this research. Foremost, we thank the Directorate General of Antiquities and Museums in Damascus for permission to carry out this research, especially the Directors General Dr Tammam Fakouch, Dr Abdul Razak Mouaz and Dr Bassam Jamous; the Director of Excavations Dr Michel al-Maqdissi in Damascus; Sd Abdul Messih al-Baghdo in Hassake; and our representative Sd Eyad Ghanem. We gratefully acknowledge the hard work of survey assistants Fahid Juma'a and Shilan Ramadan,
}

both of the University of Damascus, and the advice and support of the Sustaining Area Survey team, especially Field Director Henry Wright, Eric Rupley and Carlo Colantoni. Funding for the Suburban Survey was provided by the British Academy, the McDonald Institute for Archaeological Research (University of Cambridge), the University of Michigan and Harvard University. Finally, we thank Henry Wright and Augusta McMahon, whose critical comments strengthened this manuscript. 
public and religious institutions, administrative technologies, evidence for trade in exotic raw materials and luxury commodities and large-scale mass production (Oates 2002). The present research project aimed to add empirical evidence for demography, spatial organisation and land-use patterns via a combination of intensive and systematic surface collection and analysis of remote sensing sources.

It is not, however, the first research into Brak's outer town. Initial observations were made by Poidebard, who combined aerial photography with excavations at the fortified structure on the north-east edge of the site that he identified as a Roman castellum (Poidebard 1934: 144 46). He was soon followed by Mallowan, whose work was focused on the central mound but did include a surveyed plan of the outer mounds (Mallowan 1947: 48-49, pl. LVI) and an unpublished trench on Tell Majnuna. The resumption of excavations under David and Joan Oates resulted in some general observations and a more detailed sketch plan (Fielden 1981: fig. 7). Along with CORONA satellite photographs (discussed below), these early observations are particularly important for reconstructing the subtle topography of the outer mound, much of which has been damaged in recent decades by deep ploughing and the expansion of pump-irrigated cotton fields.

Fielden's observations were expanded in a reconnaissance by Eidem and Warburton (1996). Important geoarchaeological studies of the site and its immediate hinterland were conducted in 1991-93 (Wilkinson et al. 2001). A high-resolution topographic survey of the central mound and outer town was undertaken in 1998 by Torben Larsen and Tim Skuldbøl, who also made a series of small soundings at the base of the central mound with the goal of establishing its chronology and extent (Emberling et al. 1999: 15-26); in 2004 the topographic survey was extended by Skuldbøl. In 2000, a $200 \mathrm{~m}^{2}$ excavation was carried out on the T2 mound on the south-eastern outer town (Emberling and McDonald 2001: 45). The project directors have continued general observations of the outer town since the resumption of excavations in 1976 (e.g. Oates and Oates 1993: 182-83, fig. 39), and recent seasons of excavations have included investigations of Tell Majnuna in the northern suburban area (see below).

Building on several earlier reconnaissance and extensive surveys (Fielden 1978-79; Meijer 1986; Eidem and Warburton 1996; Lyonnet 2000), the Tell Brak Sustaining Area Survey examined sites and landscape features in a twenty-kilometre radius around Tell Brak (see preliminary reports in Wright et al. 2006-7; Oates 2005: 28-35). As a complement to this project, the Brak Suburban Survey undertook an intensive surface examination of Brak itself. ${ }^{2}$ Our goal was to reconstruct the history of settlement on the site, with a particular focus on the chronology and spatial patterning of its urban phases. Brief reports on the spatial patterns of the fifth-fourth millennia have been published (Ur, Karsgaard and Oates 2007; Oates et al. 2007: 597) and studies of Brak's postAkkadian settlement pattern and its general urban evolution are forthcoming (Ur in press-a, Ur in press-b).

\section{Survey methodology}

Tell Brak has as long and convoluted a settlement history as any site in Syria, followed by an extensive excavation history, as a result of which the site has a very complicated morphology that is particularly challenging for a systematic surface collection (Fig. 1; see Wilkinson et al. 2001). The most ancient part of the site is the high central mound, the northern ridge of which rises over forty metres above the surrounding plain; this mound measures between forty-five and sixty hectares, depending on which contour one uses as its base. Surrounding this mound on all sides is a great expanse of outlying low mounds, most of which are only a few metres high. Some of the more prominent of these mounds have been assigned names of their own, either by the local inhabitants or by archaeologists: Tell Majnuna to the north, Tell Temmi and T2 to the east and south-east and Majnuna village to the south-west. Despite their individual designations these mounds are all contiguous components of the total settlement complex. Between them and the high mound are a series of depressions that Brak's ancient inhabitants excavated to extract mud-brick material.

\footnotetext{
${ }^{2}$ The Tell Brak Sustaining Area Survey was conducted under the field direction of Henry Wright, as part of the Tell Brak Excavation Project directed by David and Joan Oates.
}

The Suburban Survey was jointly designed and supervised by Jason Ur and Philip Karsgaard. 


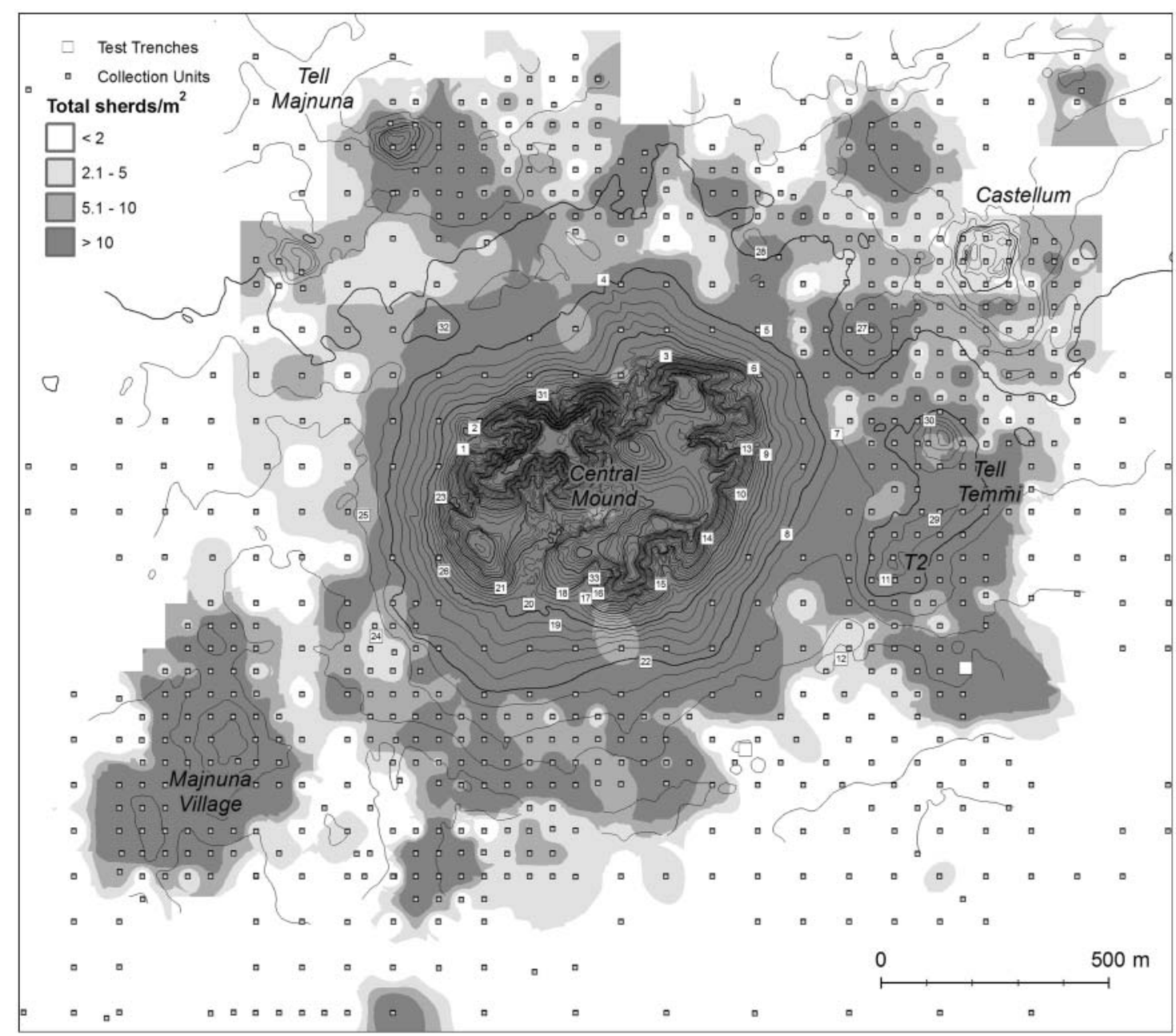

Fig. 1 The Tell Brak Settlement Complex, with surface collection units, interpolated density of surface artefacts, test trenches and major topographical designations indicated. Contours at $1 \mathrm{~m}$ intervals.

The entire area of settlement covers almost three hundred hectares, although at no time was the entire area settled simultaneously.

In designing the survey, we elected to avoid the high central mound because excavation since the time of Mallowan has transformed its surface assemblage, mostly by the erosion of excavation dumps. For this part of the settlement complex the excavations already provide a broad spatial understanding of settlement. We therefore began our survey arbitrarily at the boundary of modern cultivation on the slopes of the high mound (roughly the $340 \mathrm{~m}$ ASL contour), with the understanding that much of its immediate slopes were composed of artefacts that had eroded from their point of original discard. Our area of interest thus included the central mound's lower slopes and the entire expanse of its outer town. An attempt was made to extend the survey well beyond the boundaries of the site in all directions, not only to define the edges of the ancient settlement but also to test for the presence of field scatters (see Wilkinson 2003: 117-18).

Because of the vast size of the settlement complex the survey opted for a systematic sampling method based on the methods employed in the surface collection at Hamoukar (Ur 2002, 2010c). Hundred-square-metre $(10 \times 10 \mathrm{~m})$ collection units were placed across the site according to the Universal Transverse Mercator (UTM) zone 37 north coordinate system, and based on positioning from handheld Global Positioning System (GPS) receivers. Where surface visibility was high (i.e. on fallow or harvested and grazed land) units were placed at fifty metre intervals. Where the ground was disturbed or visibility was low, we used hundred-metre intervals. Within these collection units, 
all artefacts were collected from a $2 \times 2 \mathrm{~m}$ square in one corner to assess surface artefact density. From the remaining ninety-six square metres only chronologically significant diagnostics were retained. In off-site areas, the interval was expanded to two hundred metres and all artefacts were collected from the entire $100 \mathrm{~m}^{2}$. Ultimately 963 sampling units were collected and over 55,000 sherds processed.

Ceramic dating was undertaken with reference to a survey typology initially developed by David Tucker and Tony Wilkinson for the North Jazira Project (see Ball, Tucker, and Wilkinson 1989; Wilkinson and Tucker 1995) and expanded to include new types from recent excavations including Brak itself (Ur 2010c: appendix B). Of particular significance for the Brak Suburban Survey are the fifth and fourth-millennium types, which are tied locally to the excavations at Brak in Area TW, the longest and most complete fourth-millennium sequence in northern Mesopotamia, and in Area $\mathrm{CH}$ where Late Ubaid and LC1 material has also been excavated (Oates 2002; Oates and Oates 2002). These types have been assigned absolute dates via radiocarbon analyses (Hole 2001; Wright and Rupley 2001). Where possible, we employ in this report the Tell Brak Project period designations (Table 1).

The Suburban Survey made extensive use of three remote-sensing datasets. The base map for our research was a Digital Globe QuickBird satellite image of the settlement complex, taken on 4 October 2004. ${ }^{3}$ This image captured the modern elements of the landscape, especially field patterns, tracks, roads and built features. Photographs from several missions of the declassified American CORONA intelligence satellite programme were used to map areas of mounding, anthropogenic soil discolouration and the traces of ancient trackways and canals. ${ }^{4}$ These images have proven to be especially useful for landscape archaeology throughout the Near East (for the Khabur basin, see Ur 2003, Ur 2010c, reviewed more generally in Fowler 2004). Finally, we are particularly fortunate to have access to aerial photographs of Brak and its surroundings taken by Hartmut Kühne in May 1984 (e.g. Wilkinson et al. 2001: figs. 10-11). The two latter sources were especially useful for documenting the surviving traces of Brak's radial track network and first-millennium AD irrigation system (see below).

With this methodology the Brak Suburban Survey has produced data of high resolution, both spatially and chronologically, collected and quantified in a manner that will permit comparison and independent evaluation.

\section{The history of occupation in the Brak settlement complex}

Occupation at Brak began in the Halaf period or earlier. At this time a settlement of uncertain size and character existed beneath the present high mound, partially revealed by the Area $\mathrm{CH}$ deep soundings, where Late Ubaid and LC1 material was found in association with non-residential structures, including a massive Ubaid platform of patzen bricks. The surface survey found no Ubaid sherds in the outer town, although such sherds have been noted out of context in excavations (Oates 1987) and on the surface of the central gully's colluvial delta by J. Oates and H. Wright.

\section{Brak Phase E (LC 2, Early Northern Uruk)}

The survey recovered few sherds of the LC 1 period, but with the LC 2 period the expansion of settlement had begun (Fig. 2). LC 2 ceramics were found in discrete clusters throughout the outer areas of the settlement complex, generally 200-500 metres from the edge of the high mound. Six clusters were associated with slight mounding: three in an arc in the north and east outer settlement, and three to the south-west. Each cluster covered between two and four hectares. Beyond these clusters even more dispersed settlement was detected: a seventh concentration 1000 metres to the north-east was not associated with mounding and was of much lower sherd density. Even further to the north-west, two outlying areas of uncertain extent were revealed by local officials trenching with a mechanical shovel.

\footnotetext{
${ }^{3}$ As of 13 July 2010 this image is visible via Google Maps (http://maps.google.com) and through the Google Earth program (see http://earth.google.com).

${ }^{4}$ The following missions were particularly useful: 1102 (11 December 1967), 1105 (5 November 1968), 1108 (6
}

December 1969), and 1117 (25 May 1972). These georeferenced images have been placed online and can be freely downloaded (Ur 2010b). Other CORONA scenes are available for preview and ordering through the United States Geological Survey's website (http://earthexplorer.usgs.gov). 
TABLE 1: Periodisation at Tell Brak in relation to other chronological schemes.

\begin{tabular}{|c|c|c|c|c|c|c|c|}
\hline \multicolumn{2}{|c|}{ Absolute Dates } & Brak & \multicolumn{2}{|c|}{$\begin{array}{l}\text { Tell Hamoukar } \\
\text { Survey }\end{array}$} & \multirow[t]{2}{*}{$\begin{array}{l}\text { Southern } \\
\text { Alluvium }\end{array}$} & \multirow{2}{*}{\begin{tabular}{|c|} 
Northern Mesopotamia \\
$\begin{array}{c}\text { Proto-Hassuna/ Pre-Halaf } \\
\text { (Samarra-related) }\end{array}$
\end{tabular}} & \multirow[t]{2}{*}{$\begin{array}{l}\text { LC \& EJ } \\
\text { Chronology }\end{array}$} \\
\hline \multirow{22}{*}{ 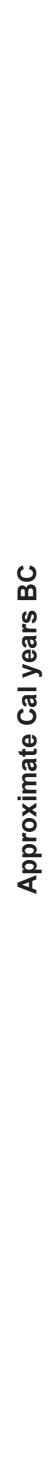 } & $6500-5900$ & $\mathbf{A}$ & Peric & d 1 & & & \\
\hline & $5900-5200$ & B & Peric & d 2 & Early Ubaid & Halaf & \\
\hline & $5200-4400$ & C & Peric & d 3 & Late Ubaid & Northern Ubaid & \\
\hline & $4400-4200$ & D & \multirow{2}{*}{\multicolumn{2}{|c|}{ Period 4}} & Terminal Ubaid & Terminal Ubaid & LC1 \\
\hline & $4200-3900$ & E & & & Early Uruk & Northern Early Uruk & LC2 \\
\hline & $3900-3600$ & \multirow{2}{*}{$\mathbf{F}$} & \multirow{3}{*}{$\begin{array}{l}\text { Period } \\
5 b\end{array}$} & & \multirow{2}{*}{ Middle Uruk } & Northern Middle Uruk & LC3 \\
\hline & $3600-3200$ & & & \multirow{2}{*}{$\begin{array}{c}\text { Period } \\
5 a\end{array}$} & & & LC4 \\
\hline & $3200-3000$ & G & & & Late Uruk & Late Uruk & LC5 \\
\hline & $3000-2900$ & H & \multirow{3}{*}{\multicolumn{2}{|c|}{ Period 6}} & Jemdet Nasr & Post-Uruk & EJ 0 \\
\hline & $2900-2600$ & J & & & ED I through early III & \multirow{2}{*}{ Ninevite 5} & EJ I \\
\hline & $2600-2400$ & K & & & Early Dynastic IIla & & EJ II \\
\hline & $2400-2300$ & L & \multirow{3}{*}{\multicolumn{2}{|c|}{ Period 7}} & Early Dynastic IIIb & Post-Ninevite 5 & EJ III \\
\hline & $2300-2100$ & $\mathbf{M}$ & & & & kadian & EJ IV \\
\hline & $2100-2000$ & \multirow{2}{*}{$\mathbf{N}$} & & & Ur III & Post-Akkadian & \multirow{2}{*}{ EJ V } \\
\hline & $2000-1850$ & & & & Isin-Larsa & Middle Bronze I & \\
\hline & $1850-1500$ & $\mathbf{P}$ & Peric & d 8 & Old Babylonian & $\begin{array}{c}\text { Middle Bronze II/ } \\
\text { Khabur }\end{array}$ & \\
\hline & $1500-1275$ & $\mathbf{Q}$ & \multirow{2}{*}{\multicolumn{2}{|c|}{ Period 10}} & \multirow{2}{*}{ Kassite } & Mitanni & \\
\hline & \multirow{2}{*}{$1275-900$} & $\mathbf{R}$ & & & & \multirow{2}{*}{ Middle Assyrian } & \\
\hline & & & \multirow{2}{*}{\multicolumn{2}{|c|}{ Period 11}} & Post-Kassite & & \\
\hline & $900-600$ & s & & & \multicolumn{2}{|c|}{ Neo-Assyrian/Iron II } & \\
\hline & $600-330$ & & \multicolumn{2}{|c|}{ Period 12} & $\begin{array}{l}\text { Neo-Babylonian/ } \\
\text { Achaemenid }\end{array}$ & Post-Assyrian & \\
\hline & $320-150$ & & \multicolumn{2}{|c|}{ Period 13} & \multicolumn{2}{|c|}{ Seleucid/Hellenistic } & \\
\hline \multirow{6}{*}{ 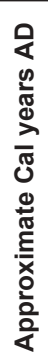 } & $150-224$ & $\mathrm{~T}$ & \multicolumn{2}{|c|}{ Period 14} & \multicolumn{2}{|c|}{ Parthian/Roman } & \\
\hline & $224-600$ & & \multicolumn{2}{|c|}{ Period 15} & Sasanian & Byzantine/Sasanian & \\
\hline & \multirow[b]{2}{*}{$600-1000$} & & \multirow{2}{*}{ Period 16} & & Late Sasan & ian/Early Islamic & \\
\hline & & & & $\begin{array}{c}\text { Period } \\
17\end{array}$ & Early Isla & amic/Abbasid & \\
\hline & $1000-1500$ & & Period 18 & & Midd & le Islamic & \\
\hline & $1500-1900$ & & Period 20 & 19 & Late Isla & Imic/Ottoman & \\
\hline
\end{tabular}

The surface distribution is complemented by excavations of LC 2 levels on the high mound. In TW Level 21 excavation has revealed extensive areas of multiple fire installations and, in Level 20, a complex of buildings including the north-western corner of a monumental structure with two-metre thick walls and a massive basalt threshold, adjacent to a sherd-paved street leading to a 


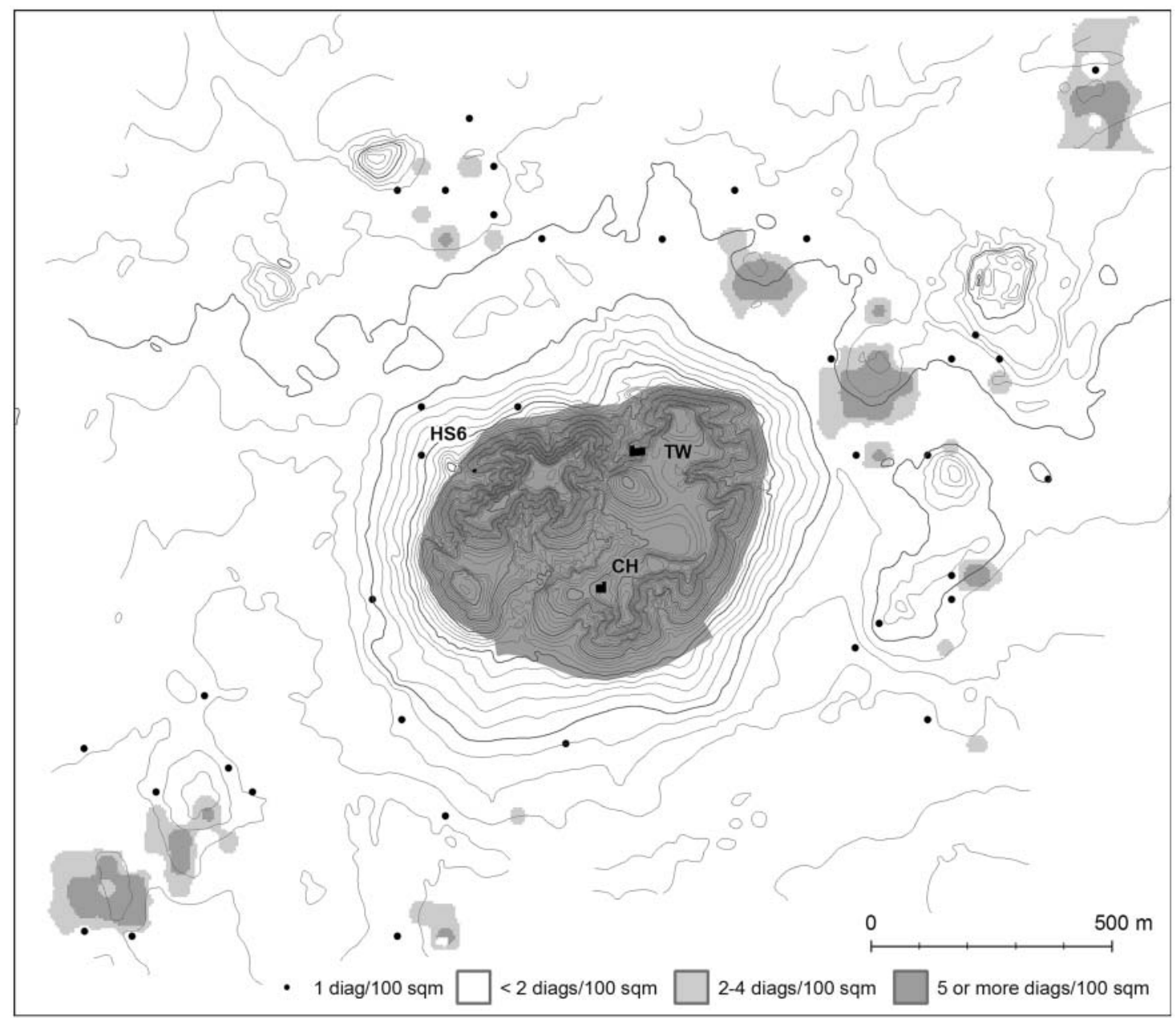

Fig. 2 Phase E (LC 2, Early Northern Uruk) sherd scatters at Tell Brak.

northern entrance to the city (Oates et al. 2007). At the north-western corner of the site, in Area HS6, a similarly monumental wall was excavated (Matthews 2003b). Finally, at the southern part of the site, in situ LC 2 remains have been found in Area CH. If we assume continuous occupation between these areas, it would appear that the central mound was entirely settled. Using a conservative estimate of the size of the high mound, the settled area covered 55 hectares in the late fifth to early fourth millennia BC.

\section{Brak Phase F (LC 3-4, Middle Northern Uruk)}

The dispersed pattern at Brak continued to evolve in the LC 3 and 4 periods; it was in the latter phase that intrusive south Mesopotamian (Middle Uruk) pottery first appears. The indigenous low-fired, heavily chaff-tempered ceramics of these two phases are similar but not identical, and it is hoped that this critical phase can be subdivided with further analysis. In the outer settlement, occupation expanded and intensified so that several Phase E clusters grew together, filling in the formerly vacant spaces between them. Two of the three clusters to the south-west expanded to become a continuous area of settlement. The entire north-eastern arc was continuously settled, although at variable density (Fig. 3).

At this point, we must be certain that these sherd scatters derive from ancient settlement, and not from erosion or other taphonomic factors. For example, sherd scatters appear on the lower slopes of the central mound. These are not indicators of settlement but can instead be attributed to the erosion of the high mound. The east-west low-density cluster south of the high mound, however, 


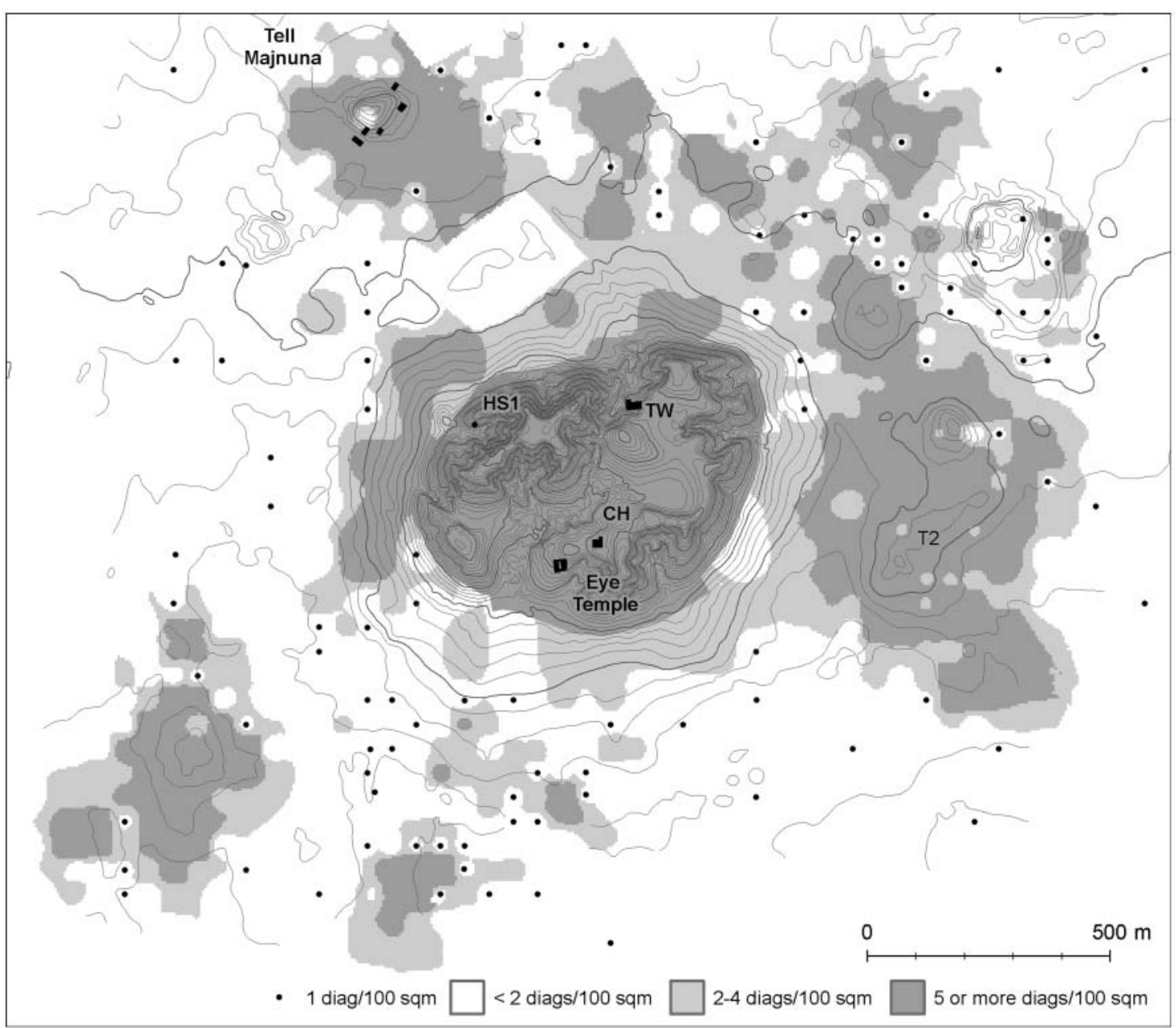

Fig. 3 Phase F (LC 3-4, Middle Northern Uruk) sherd scatters at Tell Brak.

is beyond the area of erosion and probably derives from in situ settlement remains. In fact, we may be under-representing the size of this particular cluster. The area between it and the high mound is covered by a delta of colluvial material from Brak's central gully. This cluster may have extended further north, possibly up to the southern mound edge. Brak's geomorphological dynamics make size estimation a tricky undertaking, but after excluding sherd distributions caused by erosion, we estimate the total settled area of the LC 3-4 settlement at one hundred and thirty hectares.

Brak's Phase F is well known from Mallowan's and more recent excavations on the high mound, which further demonstrate the development of social complexity that was emergent in the LC 2 period (Oates 2002). Most famous is the Eye Temple, but excavation in Area TW has recovered a small wood-panelled building containing eye idols, a jewellery hoard and the earliest known semi-columned façade, a feature later associated with temples. Eye idols were found in this building, and the main room had been lined with wooden panels. An extraordinary hoard of jewellery was discovered in the associated courtyard (Oates and Oates 1993; Emberling and McDonald 2003: figs. 12-13). Elite domestic structures were associated with evidence for large-scale feasting (Emberling and McDonald 2001: 21-31). Smaller excavations and surface scraping demonstrate LC 3 occupation across the high mound (Matthews 2003a).

Additional clues to the spatial arrangement of activities in the outer town come from two locations where excavations have revealed activities not otherwise recognised on the central mound. To the south-east, a small sounding on T2 revealed evidence for the manufacture of ceramics (Emberling and McDonald 2001: 45). These data are complemented by T2's surface assemblage, which featured fragments of ceramic ring scrapers, used in thinning vessel walls prior to firing. 
Additional evidence comes from the north side of the settlement complex. Tell Majnuna is a small mound at its northern edge. In the spring of 2006, the municipality used a mechanical digger to cut a trench around a new grain-storage area. This trench revealed middens on either side of Tell Majnuna. In addition to dense ceramics these trash layers contained other sorts of debris: discarded clay objects, sealings, ash and animal remains. Most unexpected were abundant adult human remains in partially articulated state (McMahon and Oates 2007; Sołtysiak 2008; McMahon 2009). Some bodies were well articulated, and must have been at least partially fleshed at the time of deposition. Other elements, particularly skulls, were found in concentrations that imply their deliberate disarticulation and collection. This deposit represents the highest concentration of adult human remains found at LC Brak, and indeed anywhere in Mesopotamia at this time.

Together, Majnuna and T2 demonstrate in Phase F the range of differentiated economic and social activities attested in the outer settlement that are not otherwise represented in the extensive excavations on the high mound. Such activities would be difficult or impossible to discern from surface remains alone.

\section{The evolution of urbanism at Brak in Phases E-F (Early to Middle Northern Uruk)}

To summarise, the LC 2 period at Brak witnessed the apparently rapid formation of a spatially extensive settlement. It was characterised by dispersed clusters of occupied space, with non-settled zones in between. Political hierarchy is visible through the presence of elite architecture and artefactual signs of stratification in Areas TW and HS6. Settlement continued into Phase F by expanding inward and partially or completely filling the voids in settlement. The abundance of surface ceramics also suggests increased use and discard of pottery, which we interpret as evidence of increased density of occupation. Thus not only did the spatial extent of settlement increase, the density of human occupation increased simultaneously.

In terms of sociopolitical organisation during this initial phase of urban formation, our results present more questions than answers (Ur, Karsgaard and Oates 2007). The maintenance of spatial separation suggests underlying social distance. These intervening spaces might have marked corporate sub-groups within the larger settlement. The discrete household clusters might have been distinct neighbourhood communities, which were sufficiently socially or politically separate that spatial distance between them was maintained. In this sense they may resemble an expanded version of later nucleated Mesopotamian cities, where neighbourhoods were divided by gates and walls instead of distance.

The countryside surrounding Tell Brak was densely occupied by smaller towns, villages and hamlets at this time, but Brak itself resided in a relatively empty area, with no sites within three kilometres. This arrangement probably resulted from intensive cultivation in Brak's immediate hinterland, necessary in order to sustain its large population (Wright et al. 2006-7: 10-11).

The empirical data from Brak establish that the initial appearance of urbanism in the Near East was at minimum a multi-centric phenomenon. By the time that strong evidence appears for north-south interactions, around $3600 \mathrm{BC}$, Brak had already witnessed a half-millennium of urban evolution. It would be premature to exclude the possibility of cultural interaction at an earlier stage, but at present all evidence suggests that this was an indigenous process.

\section{Brak Late Phase F/G (LC 4-5, Southern Uruk)}

Our discussion thus far has been limited to the distribution of indigenous ceramic types on the site's surface, but Brak is of course a site of major significance within the phenomenon of the Uruk expansion. Based on the precise stratification in Area TW (Oates 2002), southern Mesopotamian material culture of Middle Uruk date first appears in the LC 4 period (later Phase F), alongside material of local style. In subsequent TW levels Late Uruk ceramics appear exclusively, although it is not certain that the disappearance of local material occurred elsewhere on the site.

The morphological differences between Middle and Late Uruk ceramics are rarely useful in surface assemblages, so our distribution of southern Uruk material represents the entire duration of the southern presence (Fig. 4). Uruk sherds cluster in two locations in the outer town. The first is a discrete low mound to the south-west of the central mound. The material includes the ubiquitous 


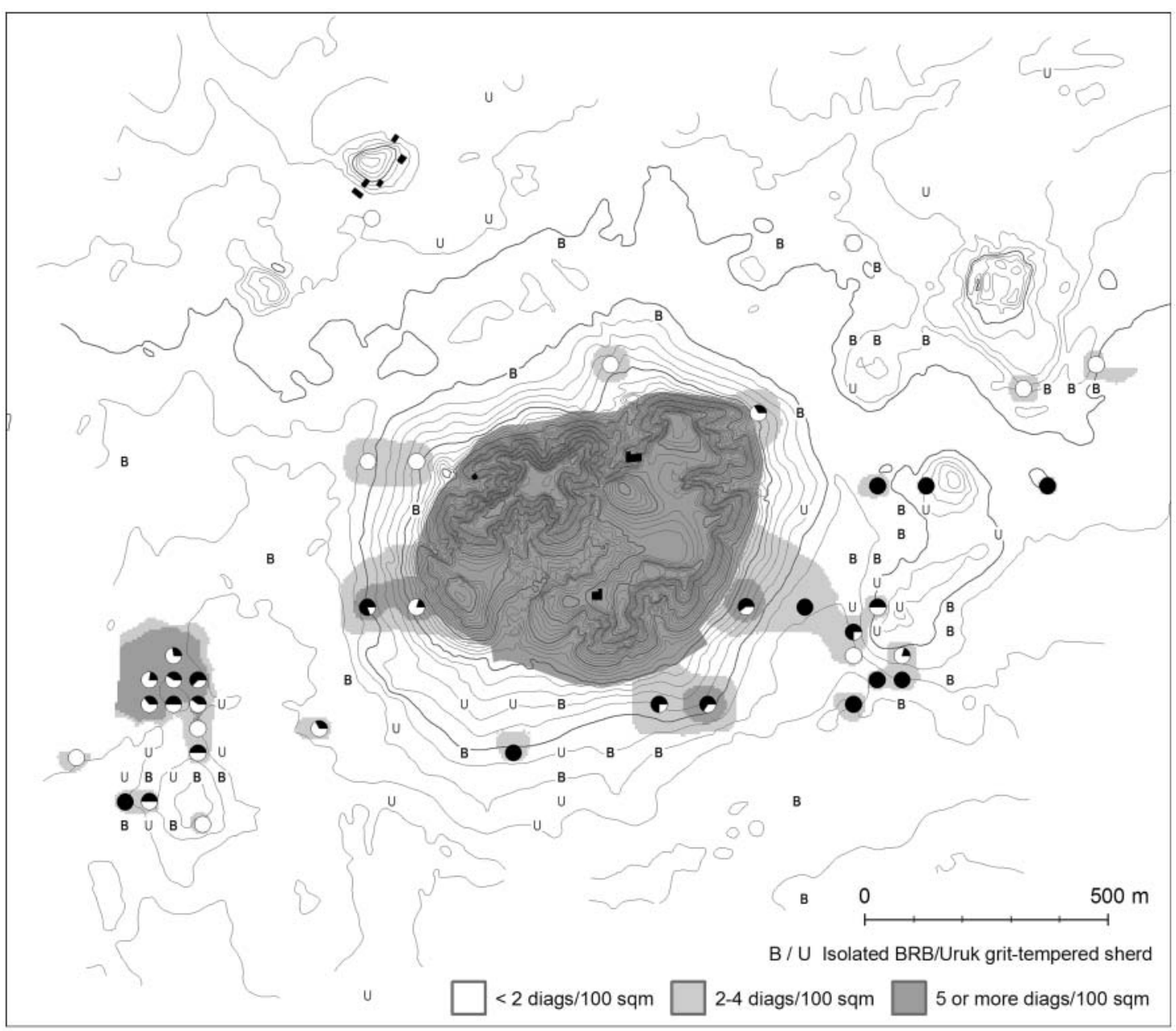

Fig. 4 Phase G (LC 4-5, Middle and Late Southern Uruk) sherd scatters at Tell Brak. Pie charts indicate relative percentages of bevelled-rim bowls (white) and grit-tempered Uruk diagnostics (black).

bevelled-rim bowls but also a high proportion of grit-tempered forms, including lugged vessels and drooping spouts. The second area is a more extensive cluster at T2, again with both bevelled-rim bowls and grit-tempered types. The scatters of southern material on the central mound's lower slopes can be attributed to erosion from the main mound, which appears to have been fully settled. In both of the outer town clusters the surface assemblage also includes contemporary local material, but the percentage of southern material in the south-western cluster is substantial. For this discrete area of settlement characterised by intrusive material it may be appropriate to consider the model of the Old Assyrian kārum at Kültepe in Anatolia; a similar interpretation has been suggested for a small site adjacent to the mound at Hamoukar (Ur 2010c: 150). Any definitive conclusions regarding the nature of intrusive Uruk settlement in the outer town must await excavation.

\section{The mid-late third millennium BC (Brak Phases $L-N$ )}

Settlement at Brak contracted at the end of the fourth millennium. Over the subsequent four thousand years, Brak's size and spatial organisation fluctuated dramatically. Proto-Ninevite and Ninevite 5 settlement (Phases $\mathrm{H}-\mathrm{K}$ ) was limited to the high mound, and included a small temple structure and associated sealing activities (Matthews 2003a). Few remains of this time period have been excavated, however. Around $2600 \mathrm{BC}$, alongside the reappearance of large institutional households (Oates, Oates and McDonald 2001), occupation expanded outward once more, although in a form different from that of Phase F. 


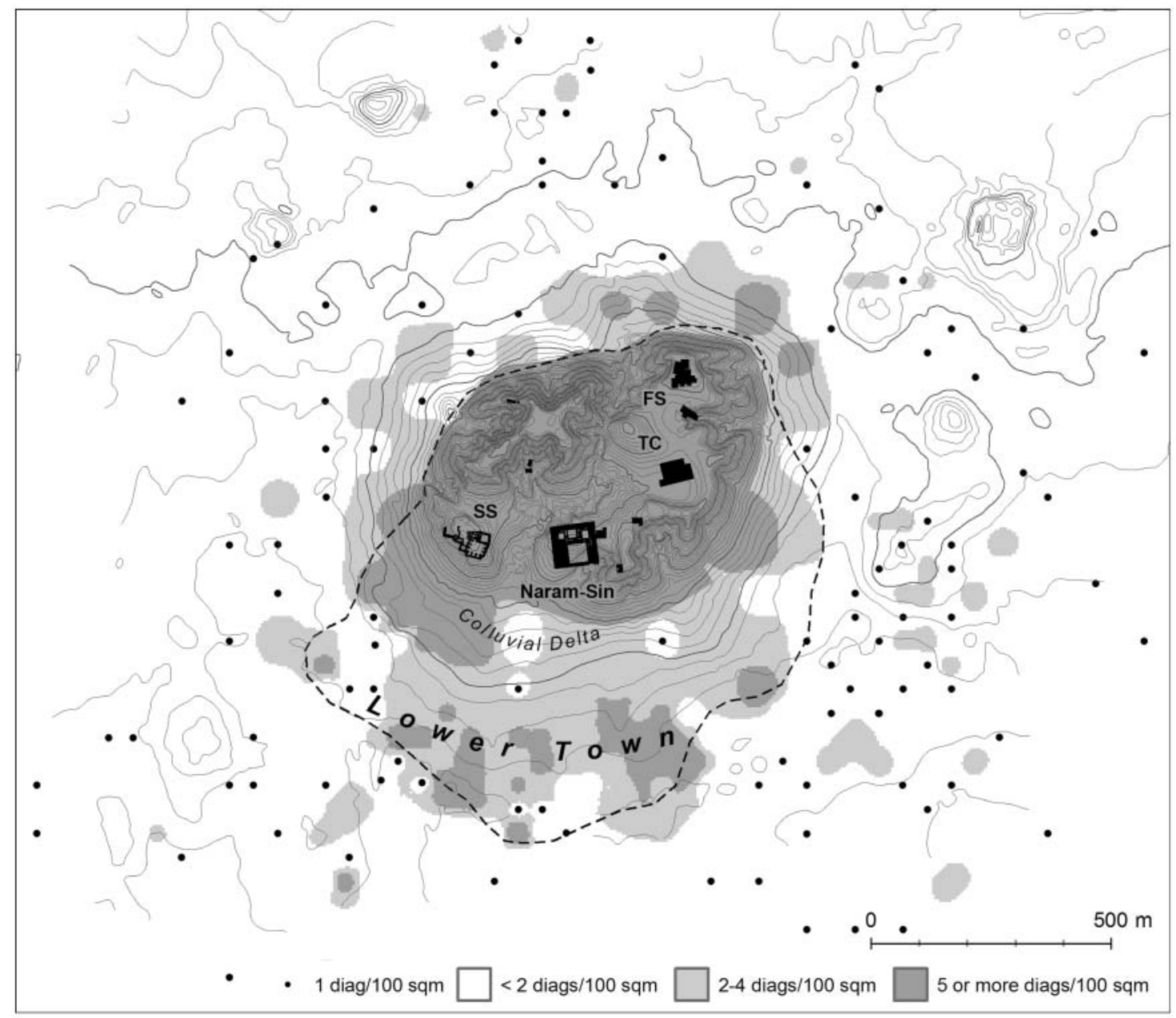

Fig. 5 Phase L-N (Early Dynastic III, Akkadian, post-Akkadian) sherd scatters at Brak. Dashed line indicates the approximate extent of the settlement.

Settlement in Phases L-N (mid- to late third millennium BC) consisted of the fully occupied central mound, with a lower town to its south (Fig. 5). As seen previously for Phase F, a dense scatter of ploughed-out ceramics of this date was recovered south and beyond the colluvial delta of Brak's central gully. On the analogy of Brak's contemporaries at Leilan, Mozan, Hamoukar, Khoshi and Kazane, we assume that this lower town runs underneath the colluvium and was contiguous with the central mound. If this assumption is correct, third-millennium Brak, now known as Nagar, would approximate the "classic" form of northern Mesopotamian urbanism: a high citadel with largely monumental structures and an adjacent lower, presumably residential, settlement area. The largest of these cities range between ninety and one hundred and twenty hectares (e.g. Leilan, Hamoukar and Mozan), but on present reckoning Brak was substantially smaller at only seventy hectares, despite its politically dominant position. Thus the situation at Brak warns against simplistically equating site size with political rank.

The landscape around the capital at Nagar was extensively modified and exploited at this time. Like many contemporary settlements, its agricultural hinterland was intensively cultivated and was traversed by dozens of kilometres of trackways (Fig. 6). The agricultural evidence comes in the form of a continuous scatter of small and abraded potsherds in the plough zone, which are best interpreted following Wilkinson (2003: 117-18) as evidence of manuring with settlement-derived refuse. The patterning and density of field scatters around Brak are comparable to the densities around Hamoukar and Tell al-Hawa (Ur 2010c; Wilkinson and Tucker 1995: 19-23). These fields would 


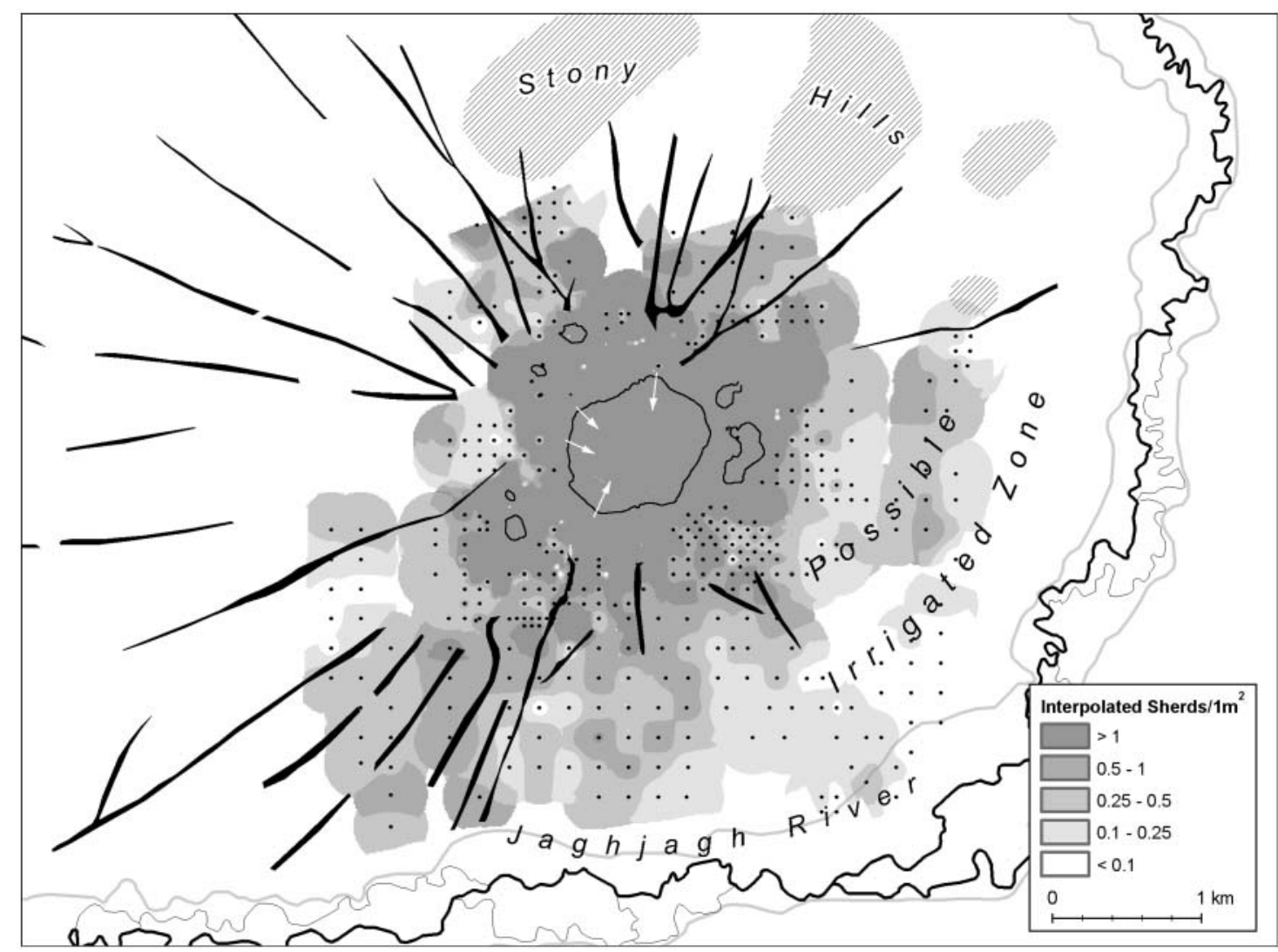

Fig. 6 Field scatters and hollow ways around Tell Brak. White arrows indicate major central mound gullies. Dots indicate off-site field scatter collection units. Abbasid-period irrigation has damaged or removed earlier landscape features at the eastern side of the site complex.

have constrained movement of human, animal and vehicle traffic onto the trackways that ran between them, causing the latter to erode and thus forming hollow ways. Many of these features had been mapped previously via CORONA imagery (Ur 2003) and could now be checked on the ground, including micromorphological study of sections through them (Wilkinson et al. 2010). Brak's radial trackway pattern is particularly large, with some features extending up to five kilometres to the west and north-west. An absence of trackway features to the south-east may be related to irrigation in the Abbasid period (see below).

The surviving hollow-way features articulate with the site in ways that suggest ancient gates or points of access. To the north, the trackways converge on three points where gullies have cut into the mound: at the western end of the mound, at the north-western edge near the HS spur, and at the TW gully to the north-east. These points might all have been access points, although we hesitate to suggest whether the gates inspired the gully formation or the presence of the gullies inspired the positioning of the gates.

The trackways leading to the mound from the south form a more complex pattern. A major feature aligns precisely with the large central gully that drains the mound between Area SS and the Naram-Sin building. Several other features appear to articulate with breaks in a broad and slightly elevated feature that we hypothesised might be the remains of a city wall. A section dug through this feature in 2006 revealed yellow silt piled on top of an earlier Holocene soil horizon. The feature itself had been transformed by subsequent soil-formation processes, so no bricks could be discerned, although it could have been constructed of pisé or fill within a casemate structure. An early second-millennium feature cut into it, providing a terminus ante quem (Henry Wright, personal communication). 
The nature or existence of a collapse or abandonment event at the end of the third millennium has been a major research issue for northern Mesopotamian archaeology (Weiss et al. 1993; recent reviews and critiques in Koliński 2007; Kuzucuoğlu and Marro 2007; Ur 2010a), and the Suburban Survey intended to contribute demographic data to this discussion. To some extent our efforts were frustrated, however, by the nature of the ceramic assemblage, the primary means of determining settlement chronology from this time. Publications from Brak, Rimah, Chagar Bazar, Taya and elsewhere have illustrated post-Akkadian (Brak Phase N) ceramic assemblages (Oates 2001; Oates and Oates 2001; McMahon and Quenet 2007; Reade 1982: pl. 5). Unfortunately the most distinctive types occur infrequently, and many types are similar or identical to their Akkadian antecedents. The few viable post-Akkadian diagnostics, above all comb-incised decoration, are not to be found on Brak's outer mounds, which suggests that the lower town was abandoned some time during or immediately after the Akkadian period (Ur in press-a). This process was one of settlement reduction, not abandonment, however; all major central-mound excavations have found the remains of Phase $\mathrm{N}$ settlement, although often in a very different form from the Akkadian buildings beneath them (Oates, Oates and McDonald 2001; Emberling and McDonald 2003: 37-56). Brak certainly underwent substantial changes in the late third and early second millennia, whether social or environmental, but its inhabitants met these challenges in ways other than collapse.

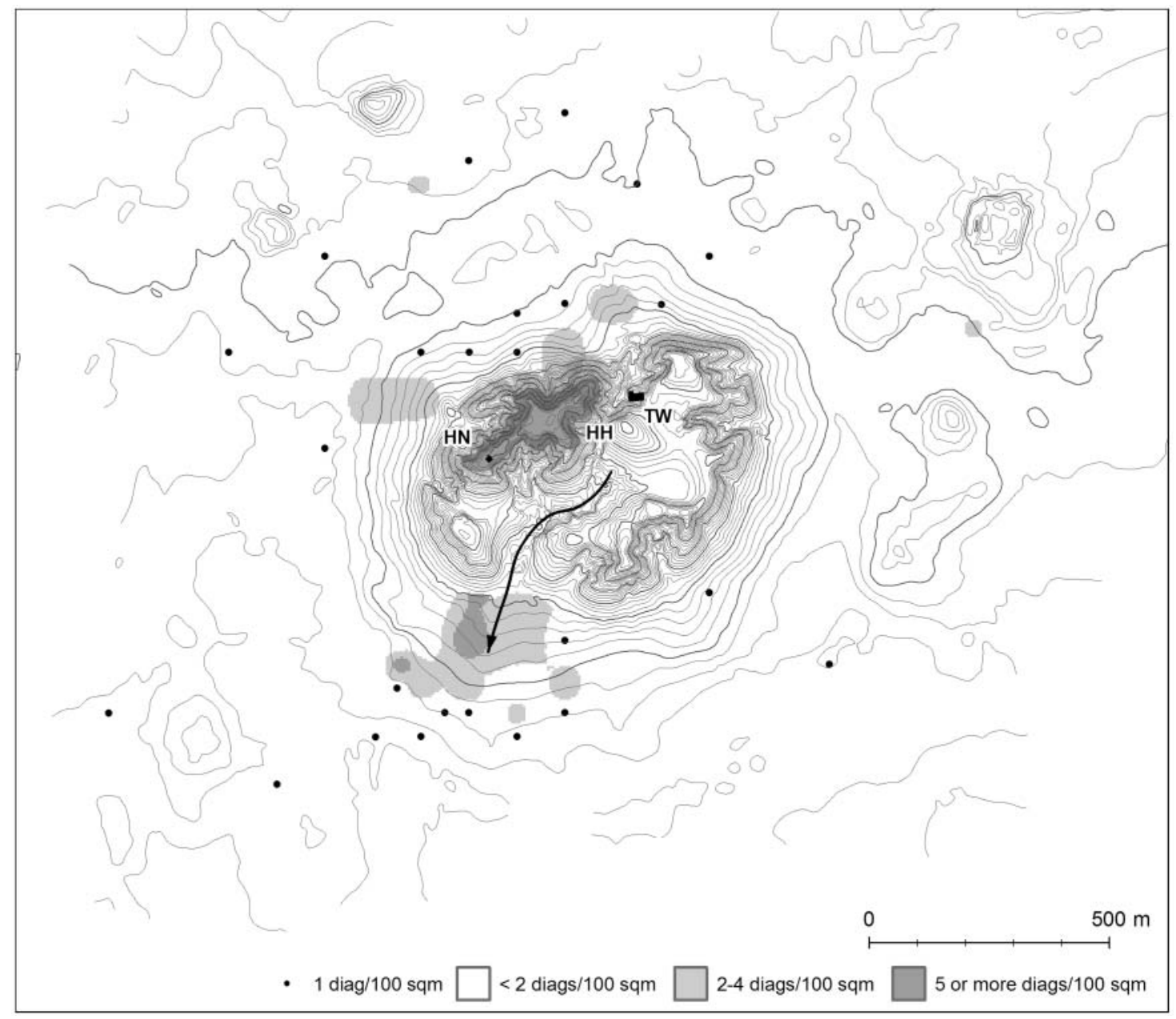

Fig. 7 Phase P (Khabur/Old Babylonian, Middle Bronze Age) sherd scatters at Brak. Arrow indicates the direction of drainage for the main central mound gully. 


\section{Brak Phase P (KhaburlOld Babylonian, Middle Bronze Age)}

At some point early in the second millennium BC settlement at Brak was abandoned on the lower town and lower central mound but continued on the northern ridge. Excavations indicate dense residential housing (Oates, Oates and McDonald 1997) but the historically known temple of Bēlet-Nagar has yet to be identified. Unfortunately its most likely position lies beneath the Mitanni Palace at the northern end of the ridge. Sherd scatters of this phase cover the northern lower slopes of the central mound and the area immediately south of Area SS (Fig. 7). In both cases these scatters result from erosional transportation, rather than proximate settlement. Sherds on the northern slopes have simply washed down from occupational layers on the north ridge, and from excavation dumps from Area HH. The southern sherd scatters have been transported further but their position on the main gully's large colluvial delta (Wilkinson et al. 2001:2-4) is a product of erosion rather than settlement. Even today heavy storms wash out large quantities of Khabur-ware sherds from the northern ridge through this same gully. Brak's Phase P artefact patterning is an excellent example of the importance of taking natural landscape transformations into account when interpreting surface assemblages. It is likely that the region also served as seasonal pasture for mobile communities (Wilkinson 2002; Ristvet 2008), but they have left no discernable trace in the surface assemblage.

\section{Brak Phase Q (Mitanni-Middle Assyrian, Late Bronze Age)}

Under Mitanni rule, Brak's high north ridge was occupied by an elite palace-temple complex and a small associated cluster of residences; the rest of the central mound was not settled (Oates, Oates

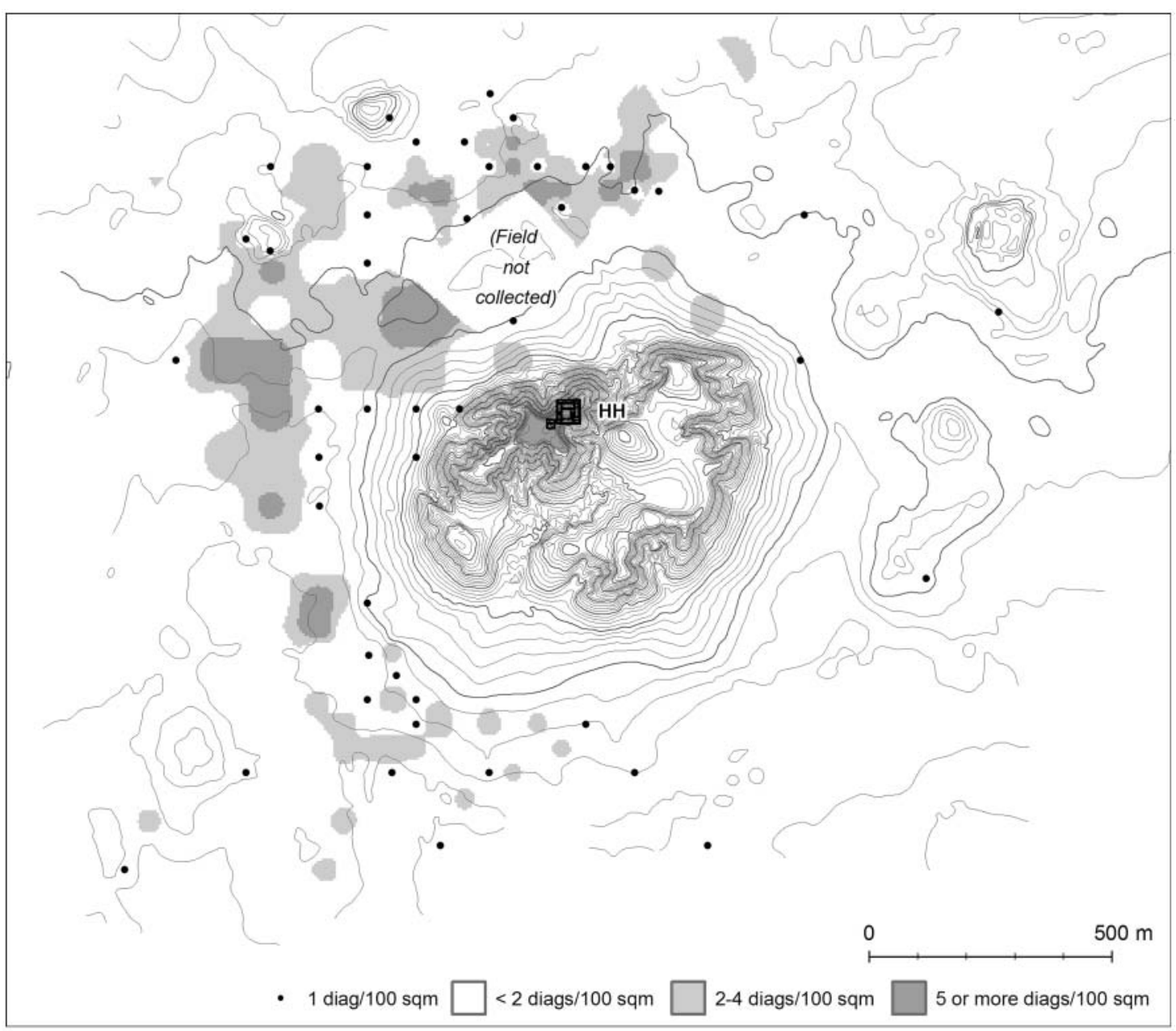

Fig. 8 Phase Q (Mitanni-Middle Assyrian, Late Bronze Age) sherd scatters at Brak. 
and McDonald 1997; McMahon and Oates 2007). Late Bronze Age sherds have been recognised in the fields below the Area HH excavations since the 1980s. Now the systematic survey has revealed the full extent of a substantial lower-town settlement (Fig. 8). Ceramic distinctions between the Mitanni and subsequent Middle Assyrian periods are subtle and rather difficult to make via surface assemblages, but we suspect that the LBA lower-town settlement is likely to be contemporary with the substantial Mitanni occupation on the north ridge, which was destroyed sometime between 1300 and $1275 \mathrm{BC}$.

Compared to the Phase F (mid-fourth millennium) and Phases L-N (mid- to late third millennium) outer settlement, sherd density appears light and discontinuous in the LBA lower settlement. This circumstance is probably the result of modern ground conditions rather than any ancient settlement patterning. The north-western outer town has been heavily irrigated over the last ten years, and at the time of collection was under a recently harvested irrigated cereal field with dense chaff that rendered surface visibility low. Under better visibility conditions sherd density would have appeared to be similar to other parts of the outer town, and its appearance on CORONA and aerial photographs suggests a dense and spatially continuous occupation similar to other LBA settlements such as Nuzi or Tell Bazi (Otto 2006; Starr 1937).

Throughout the third and second millennia Brak may be broadly characterised as a city divided into a lower and upper town; however, the intensive suburban investigations throw into sharper focus the diversity of forms that this characterisation encompasses. Both the central mound and

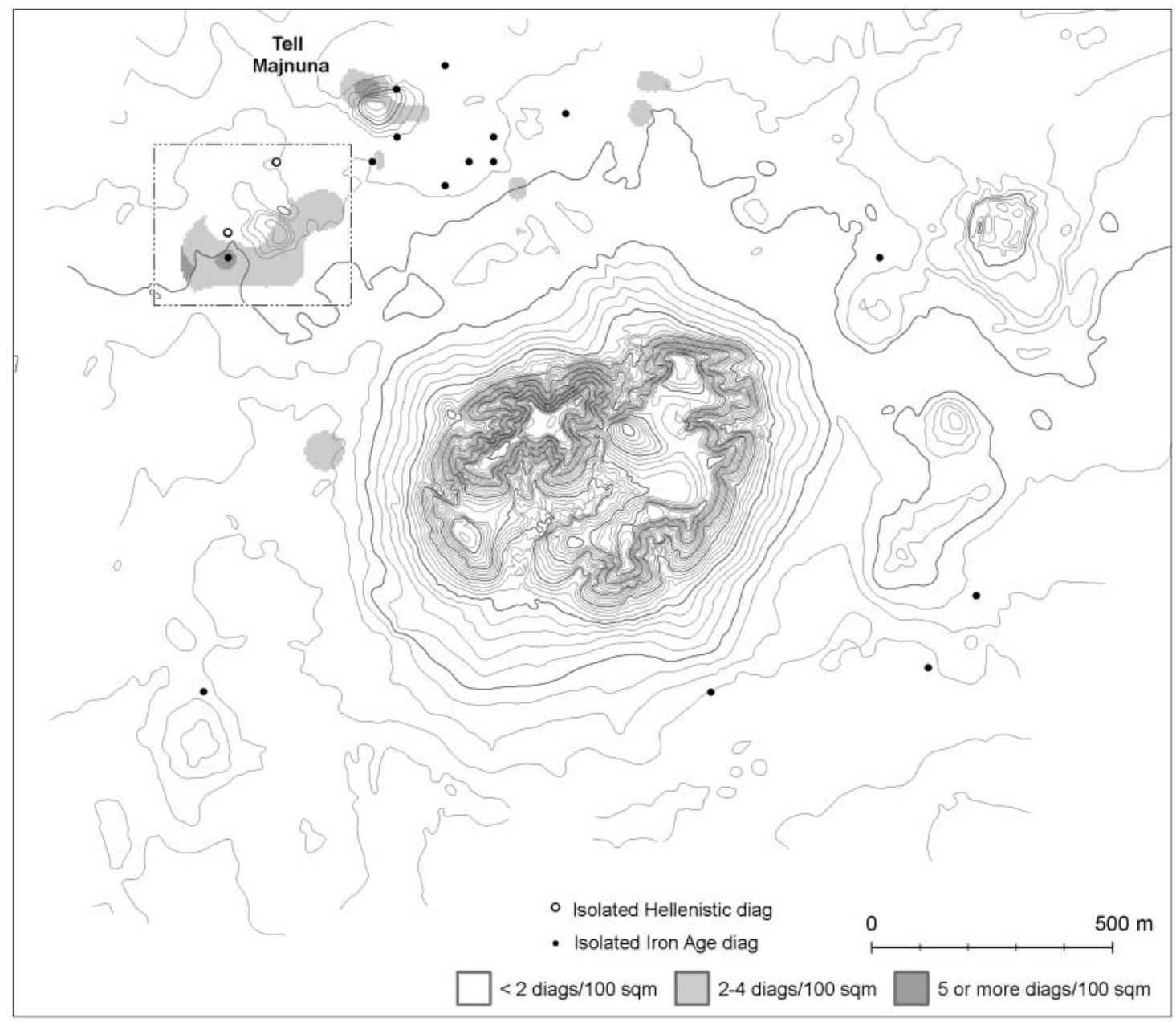

Fig. 9 Iron Age and Seleucid/Hellenistic sherd scatters at Brak. Scatter in the dashed box is Seleucid/Hellenistic; all other scatters are Iron Age. 
lower town areas of the site display differing characteristics and dynamic spatial reorganisations, while the lower town shifts considerably in spatial position, extent and organization from the mid- to late third millennium into the second (Ur in press-b). Subsequent periods show even greater transformations of Brak's urban landscape.

\section{First millennium BC (Iron Age/Neo-Assyrian, Post-Assyrian, Seleucid/Hellenistic)}

After the collapse of the Late Bronze Age city there is relatively little surviving evidence of occupation on the high mound. ${ }^{5}$ However, the outer town seems to have hosted a series of small villages (Fig. 9). A scatter of Iron Age pottery was recovered from Tell Majnuna at the northern edge of the settlement complex. Subsequently, a small Hellenistic settlement grew up on a nearby satellite mound at the north-western edge of the complex. This mound has been heavily transformed by mechanical earth-movers within the last decade, and is now surrounded by dense irrigated gardens, rendering interpretation of its surface assemblage virtually impossible. For example, Roman/Parthian sherds were reported during earlier visits by the excavation team, but no such ceramics were recovered in our systematic samples.

\section{First millennium $A D$ (Parthian-Roman, Early Islamic)}

At some point near the middle of the first millennium AD, a fortified structure was built in Brak's north-eastern outer town. It was photographed from the air in the 1920s by Antoine Poidebard. His photographs (Fig. 10) also show a mounded area to its south, and the whole Castellum complex is surrounded by linear features. Poidebard dated the structure to the Justinian era (sixth century AD) on the basis of its architecture (Poidebard 1934: 144-46). Although the area was heavily sampled, the suburban survey recovered no ceramics of the Parthian-Roman or Byzantine-Sasanian eras, although a few such diagnostics were noted in earlier visits, including a late Roman lamp (Oates and Oates 1990: 226).

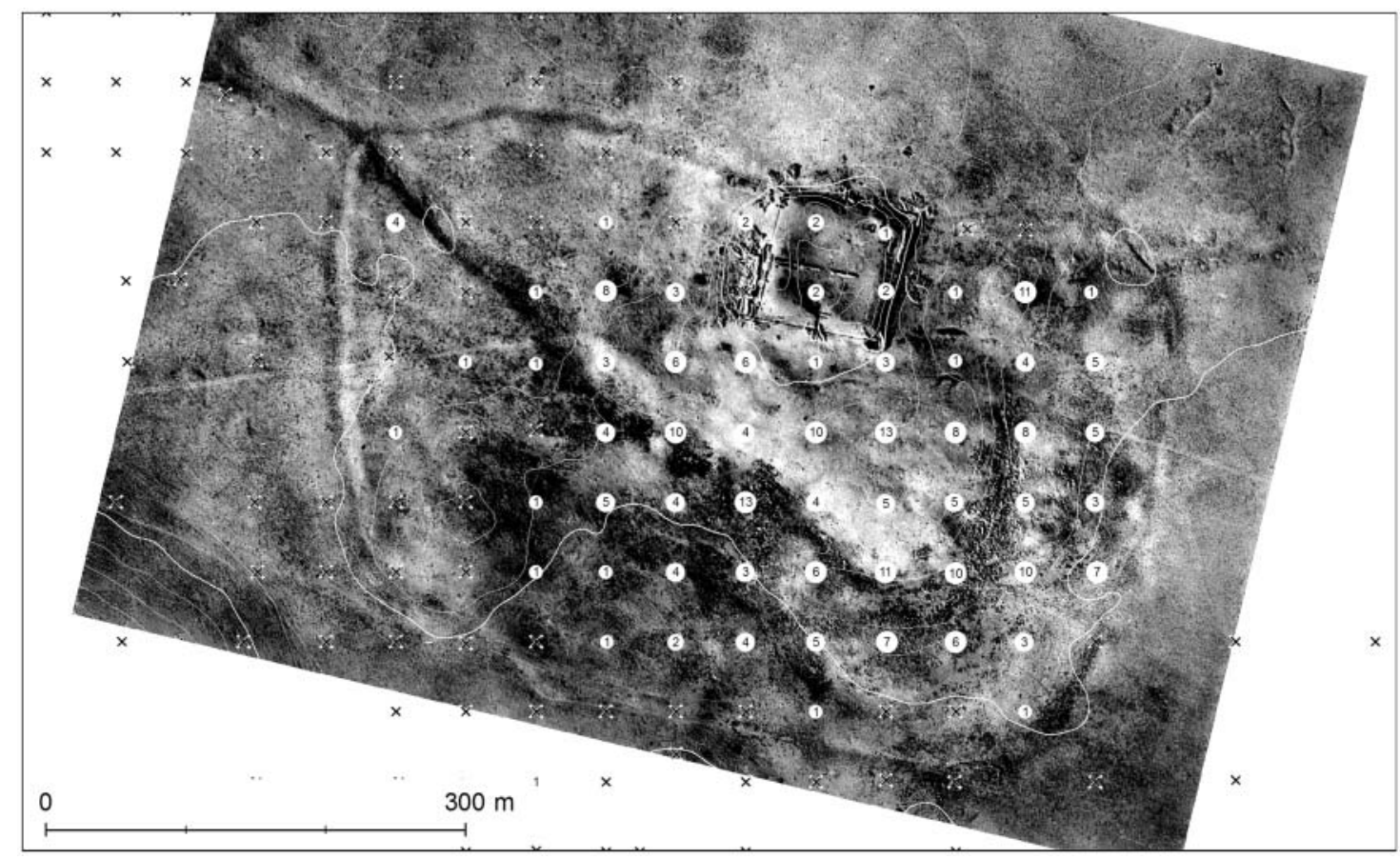

Fig. 10 Poidebard's aerial photograph of the Castellum (1934: pl. X) with superimposed topography and collection units (numbers are Abbasid diagnostic sherds $/ 100 \mathrm{~m}^{2}$ ).

\footnotetext{
${ }^{5}$ The French army found stone foundations somewhere on the highest part, presumably above the Mitanni Palace.
} At least two further levels of Middle Assyrian occupation lay 


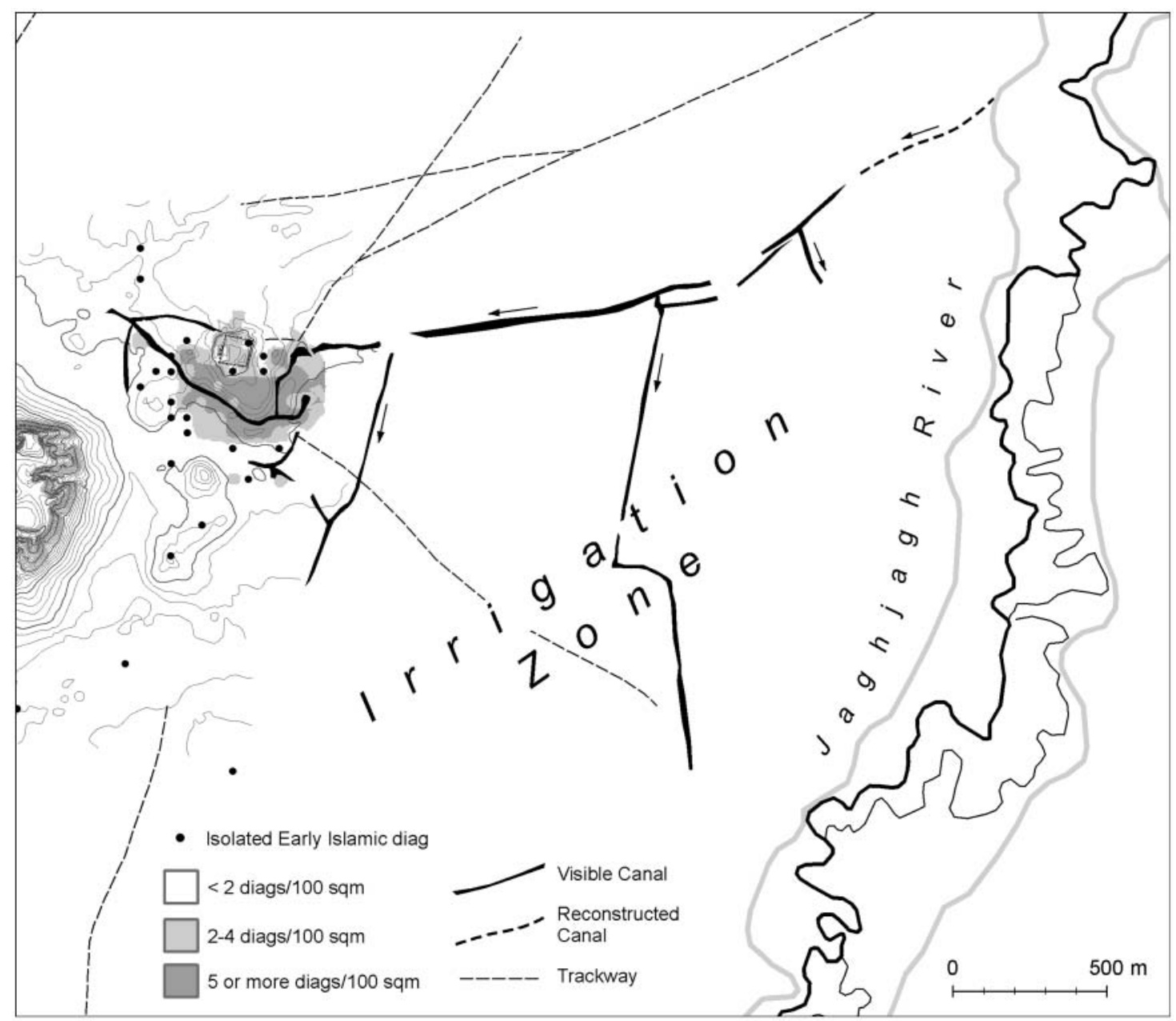

Fig. 11 The Castellum at Brak and Abbasid sherd scatters and landscape features.

Far better attested is the site's subsequent life as an early Islamic town. Our surface collection revealed abundant sherds that find their best parallels in the Abbasid materials from Tell Aswad near Raqqa (Miglus 1999). The assemblage also included the well-known blue-green glazes commonly used for early Islamic diagnostic types (Wilkinson and Tucker 1995: 105, type 74A). The scatter covers an area of fourteen hectares that corresponds closely to the mounded area visible on Poidebard's photograph and in the topographic survey.

Despite its long history of urban settlement, on present evidence it appears that Brak's Abbasid residents were also its first irrigators. Using Poidebard's photographs and CORONA imagery, a canal from the Jaghjagh River can be traced to the Castellum complex, with at least three offtakes before it reaches the Abbasid town at its north-eastern corner (Fig. 11). It then curves south around the bulk of the town and re-emerges at its western end, where it probably took advantage of the existing landscape of Bronze Age mud-brick extraction pits and hollow-way depressions to move further through the complex. The fields to the east and south-east of the town were irrigated, and this may explain why no traces of Bronze Age hollow ways have survived on this side of the site, and why field scatters are unusually low for their proximity to the site. It is possible that many areas of former settlement within the complex were cultivated by irrigation at this time, as they are today and have been since the introduction of electricity and diesel pumps in the 1980s.

\section{Conclusions}

The Tell Brak Suburban Survey and complementary evidence from the Tell Brak Sustaining Area Survey have documented the remains of the earliest urban settlement in northern Mesopotamia, and 
quite possibly in the Near East in general. Our most dramatic results pertain to this earliest phase, when Brak grew to one hundred and thirty hectares at least five centuries before the Eanna IV complex at Uruk. When southern Mesopotamians arrived at Brak in the LC 4 period, they found a thriving urban settlement. What makes Brak a particularly fascinating study in the significance of place is that it subsequently experienced several phases of population decline and then dramatic resurgence, each time in a different form (Ur in press-b). Brak's urban characteristics are dynamic and display differing spatial and organisational characteristics through time. Unlike in the alluvial plains of the south, this complex pattern of site formation does not prevent a reconstruction of the earliest phases, although it has complicated it. The sherd scatters mapped in our research provide a broad approximation of the extent and, in some places, the characteristics, of settlement. What remains is to document the dynamics of social and economic life, an undertaking that must go beyond sherds on the surface.

\section{Bibliography}

Ball, W., D. Tucker and T. J. Wilkinson. 1989. The Tell al-Hawa Project: Archaeological Investigations in the North Jazira. Iraq 51: 1-66.

Eidem, J. and D. Warburton. 1996. In the Land of Nagar: A Survey around Tell Brak. Iraq 58: 51-64.

Emberling, G., J. Cheng, T. E. Larsen, H. Pittman, T. B. B. Skuldbøl, J. Weber and H. T. Wright. 1999. Excavations at Tell Brak 1998: Preliminary Report. Iraq 61: 1-41.

Emberling, G. and H. McDonald. 2001. Excavations at Tell Brak 2000: Preliminary Report. Iraq 63: 21-54.

- 2003. Excavations at Tell Brak 2001-2002: Preliminary Report. Iraq 65: 1-75.

Fielden, K. 1978-79. Archäologische Geländebegehung im Gebiet des unteren Ğağğağ. Archiv für Orientforschung 26: 172.

- 1981. The Chronology of Settlement in Northeastern Syria during the Fourth and Third Millennia B.C. in the Light of Ceramic Evidence from Tell Brak. PhD dissertation, University of Oxford.

Fowler, M. J. F. 2004. Archaeology through the Keyhole: The Serendipity Effect of Aerial Reconnaissance Revisited. Interdisciplinary Science Reviews 29: 118-34.

Hole, F. 2001. A Radiocarbon Chronology for the Middle Khabur, Syria. Iraq 63: 67-98.

Koliński, R. 2007. The Upper Khabur Region in the Second Part of the Third Millennium BC. Altorientalische Forschungen 34: 342-69.

Kuzucuoğlu, C. and C. Marro. Editors. 2007. Sociétés humaines et changement climatique à la fin du troisième millénaire: une crise a-t-elle eu lieu en haute Mésopotamie? Varia Anatolica 19. Istanbul: Institut Français d'études anatoliennes Georges-Dumézil.

Lyonnet, B. Editor. 2000. Prospection archéologique du Haut-Khabur occidental (Syrie du N.E.) Vol. I. Bibliothèque archéologique et historique T. 155. Beirut: Institut Français d'archéoloqie du Proche-Orient.

Mallowan, M. E. L. 1947. Excavations at Brak and Chagar Bazar. Iraq 9: 1-266.

Matthews, R. Editor. 2003a. Excavations at Tell Brak Vol. 4: Exploring an Upper Mesopotamian Regional Centre, 1994-1996. Cambridge: McDonald Institute.

- 2003b. "Traces of Early Complexity: Late Fifth- to Early Fourth-Millennia Investigations", in Excavations at Tell Brak Vol. 4: Exploring an Upper Mesopotamian Regional Centre, 1994-1996. Edited by R. Matthews, pp. 25-51. Cambridge and London: McDonald Institute and British School of Archaeology in Iraq.

McMahon, A. 2009. The Lion, the King and the Cage: Late Chalcolithic Iconography and Ideology in Northern Mesopotamia. Iraq 71: 115-24.

McMahon, A. and J. Oates. 2007. Excavations at Tell Brak 2006-2007. Iraq 69: 145-71.

McMahon, A. and P. Quenet. 2007. "A Late Third Millennium BC Pottery Assemblage from Chagar Bazar (Area D, Phase II)", in Chagar Bazar (Syrie) II: Les vestiges 'post-akkadiens' du chantier D et études diverses. Edited by Ö. Tunca, A. McMahon and A. e.-M. Baghdo, pp. 69-242. Leuven: Peeters.

Meijer, D. 1986. A Survey in Northern Syria. Publications de l'Institut historique-archéologique Néerlandais de Stamboul 58. Amsterdam.

Miglus, P. A. 1999. Ar-Raqqa I: Die früislamische Keramik von Tall Aswad. Mainz am Rhein: Philipp von Zabern.

Oates, D. and J. Oates. 1990. "Aspects of Hellenistic and Roman Settlement in the Khabur Basin", in Resurrecting the Past: A Joint Tribute to Adnan Bounni. Edited by P. Mathiae, M. Van Loon and H. Weiss, pp. 227-48. Istanbul.

- 1993. Excavations at Tell Brak 1992-93. Iraq 55: 155-99.

Oates, D., J. Oates and H. McDonald. 1997. Excavations at Tell Brak, Vol. 1: The Mitanni and Old Babylonian Periods. Cambridge and London: McDonald Institute for Archaeological Research and the British School of Archaeology in Iraq. 
- 2001. Excavations at Tell Brak, Vol. 2: Nagar in the Third Millennium BC. Cambridge and London: McDonald Institute for Archaeological Research and the British School of Archaeology in Iraq.

Oates, J. 1987. A Note on 'Ubaid and Mitanni Pottery from Tell Brak. Iraq 49: 193-98.

— 2001. "The Third Millennium Pottery", in Excavations at Tell Brak, Vol. 2: Nagar in the Third Millennium $B C$, by D. Oates, J. Oates, and H. McDonald, pp. 151-94. Cambridge and London: McDonald Institute for Archaeological Research and the British School of Archaeology in Iraq.

— 2002. "Tell Brak: The 4th Millennium Sequence and its Implications", in Artefacts of Complexity: Tracking the Uruk in the Near East. Iraq Archaeological Reports 5. Edited by J. N. Postgate, pp. 111-22. Warminster: British School of Archaeology in Iraq.

- 2005. Archaeology in Mesopotamia: Digging Deeper at Tell Brak. Proceedings of the British Academy 131: $1-39$.

Oates, J., A. McMahon, P. Karsgaard, S. al-Quntar and J. Ur. 2007. Early Mesopotamian Urbanism: A New View from the North. Antiquity 81: 585-600.

Oates, J. and D. Oates. 2001. "The Late Third Millennium in the Khabur", in Beiträge zur vorderasiatischen Archäologie Winfried Orthmann gewidmet. Edited by J.-W. Meyer, M. Novák and A. Pruß, pp. 386-89. Frankfurt am Main: Johann Wolfgang Goethe-Universität.

— 2002. "The Reattribution of Middle Uruk Materials at Brak", in Leaving No Stones Unturned: Essays on the Ancient Near East and Egypt in Honor of Donald P. Hansen. Edited by E. Ehrenberg, pp. 145-54. Winona Lake: Eisenbrauns.

Otto, A. 2006. Alltag und Gesellschaft zur Spätbronzezeit: Eine Fallstudie aus Tall Bazi, Syrien. Subartu 19. Turnhout: Brepols.

Poidebard, A. 1934. La trace de Rome dans le désert de Syrie. Bibliothéque Archéologique et Historique 18. Paris: Librairie Orientaliste Paul Geuthner.

Reade, J. 1982. "Tell Taya”, in Fifty Years of Mesopotamian Discovery. Edited by J. Curtis, pp. 72-78. London: British School of Archaeology in Iraq.

Ristvet, L. 2008. Legal and Archaeological Territories of the Second Millennium BC in Northern Mesopotamia. Antiquity 82: 585-99.

Sołtysiak, A. 2008. Tell Majnuna (Syria) Season 2006. Bioarchaeology of the Near East 2: 77-94. http://www. anthropology.uw.edu.pl/bne-02-06.pdf.

Starr, R. F. S. 1937. Nuzi. Cambridge: Harvard University Press.

Ur, J. A. 2002. Surface Collection and Offsite Studies at Tell Hamoukar, 1999. Iraq 64: 15-44.

- 2003. CORONA Satellite Photography and Ancient Road Networks: A Northern Mesopotamian Case Study. Antiquity 77: 102-15.

- 2010a. Cycles of Civilization in Northern Mesopotamia, 4400-2000 BC. Journal of Archaeological Research 18: $387-431$.

— 2010b. "Landscapes of Settlement and Movement in Northeastern Syria". http://hdl.handle.net/1902.1/ 14011.

- 2010c. Urbanism and Cultural Landscapes in Northeastern Syria: The Tell Hamoukar Survey, 1999-2001. Oriental Institute Publications 137. Chicago: University of Chicago Oriental Institute.

- in press-a. "Spatial Scale and Urban Evolution at Tell Brak and Hamoukar at the End of the 3rd Millennium BC", in Looking North: The Socio-Economic Dynamics of the Northern Mesopotamian and Anatolian Regions during the Late Third and Early Second Millennium BC, Studien zur Urbanisierung Nordmesopotamiens. Edited by N. Laneri, P. Pfälzner and S. Valentini. Tübingen: Tübingen University.

— in press-b. "Urban Form at Tell Brak Across Three Millennia", in Preludes to Urbanism: Studies in the Late Chalcolithic of Mesopotamia in Honour of Joan Oates. British Archaeological Reports, International Series. Edited by H. Crawford and A. McMahon. Oxford: Archaeopress.

Ur, J. A., P. Karsgaard and J. Oates. 2007. Urban Development in the Ancient Near East. Science 317: 1188.

Weiss, H., M.-A. Courty, W. Wetterstrom, F. Guichard, L. Senior, R. Meadow and A. Curnow. 1993. The Genesis and Collapse of Third Millennium North Mesopotamian Civilization. Science 261: 995-1004.

Wilkinson, T. J. 2002. "The Settlement Transition of the Second Millennium BC in the Western Khabur", in Of Pots and Plans: Papers on the Archaeology and History of Mesopotamia and Syria Presented to David Oates in Honour of his 75 th Birthday. Edited by L. al-Gailani Werr, J. Curtis, H. Martin, A. McMahon, J. Oates and J. Reade, pp. 361-72. London: Nabu Publications.

- 2003. Archaeological Landscapes of the Near East. Tucson: University of Arizona Press.

Wilkinson, T. J., C. French, J. A. Ur and M. Semple. 2010. The Geoarchaeology of Route Systems in Northern Syria. Geoarchaeology 25: 745-71.

Wilkinson, T. J., C. A. I. French, W. Matthews, and J. Oates. 2001. "Geoarchaeology, Landscape and the Region", in Excavations at Tell Brak, Vol. 2: Nagar in the Third Millennium BC, by D. Oates, J. Oates and H. McDonald, pp. 1-14. Cambridge and London: McDonald Institute for Archaeological Research and the British School of Archaeology in Iraq. 
Wilkinson, T. J. and D. J. Tucker. 1995. Settlement Development in the North Jazira, Iraq. Warminster: Aris and Phillips, Ltd.

Wright, H. T. and E. S. A. Rupley. 2001. "Calibrated Radiocarbon Age Determinations of Uruk-Related Assemblages", in Uruk Mesopotamia and its Neighbors: Cross-Cultural Interactions in the Era of State Formation. Edited by M. Rothman, pp. 85-122. Santa Fe and Oxford: School of American Research Press.

Wright, H. T., E. S. A. Rupley, J. A. Ur, J. Oates and E. Ganem. 2006-7. Preliminary Report on the 2002 and 2003 Seasons of the Tell Brak Sustaining Area Survey. Les annales archéologiques arabes syriennes 49-50: 7-21.

Jason Ur

Dept of Anthropology

Harvard University

Peabody Museum 57F

11 Divinity Avenue

Cambridge MA 02138

U.S.A.

jasonur@fas.harvard.edu

\section{Joan Oates}

McDonald Institute for Archaeological

Research

University of Cambridge

Downing Street

Cambridge CB2 3ER

jlo29@cam.ac.uk
Philip Karsgaard

School of History, Classics and Archaeology

University of Edinburgh

Old High School

Infirmary Street

Edinburgh EH1 1LT

pdkarsgaard@gmail.com 